\title{
Mainstream Smoke Chemical Analyses for 2R4F Kentucky Reference Cigarette*
}

\author{
by \\ P.X. Chen, S.C. Moldoveanu \\ Brown and Williamson Tobacco Corporation, Macon, GA, 31217, USA.
}

\section{SUMMARY}

A new reference cigarette, $2 \mathrm{R} 4 \mathrm{~F}$, has been designed to replace the $1 \mathrm{R} 4 \mathrm{~F}$ Kentucky reference cigarette. This new cigarette has virtually the same blend composition as the $1 \mathrm{R} 4 \mathrm{~F}$ cigarette. However, the $1 \mathrm{R} 4 \mathrm{~F}$ cigarette was made in 1983 and the variation in the tobacco from crop year to crop year as well as the difference in the age of the two cigarettes were expected to generate differences in the smoke chemistry. A study done for the quantitation of more than 44 analytes in smoke, including most compounds considered as biologically active, is presented in this report. The analyses were performed by six independent laboratories using a variety of analytical techniques. The smoking was performed using International Standard (ISO) recommendations. The results showed only small differences between the two cigarettes regarding "tar", nicotine and carbon monoxide (CO), as well as for aminonaphthalenes, resorcinol, and some aldehydes. Although the two reference cigarettes were made as close as possible, the concentrations of a significant number of analytes in the smoke differed between $10 \%$ to $30 \%$. Specific trace compounds in the blend such as metals and tobacco specific nitrosamines (TSNA), which may influence the smoke composition, were also different between the two cigarettes. The level of lead, in particular, was very different in tobacco between 1983 and 2002. [Beitr. Tabakforsch. Int. 20 (2003) 448-458]

\section{ZUSAMMENFASSUNG}

Eine neue Referenzzigarette mit der Bezeichnung 2R4F ist entwickelt worden, um die Kentucky-Referenzzigarette $1 \mathrm{R} 4 \mathrm{~F}$ zu ersetzen. Diese neue Zigarette hat fast genau die gleiche Mischungszusammensetzung wie die 1R4F Zigarette. Die 1R4F Zigarette wurde jedoch 1983 hergestellt und es war anzunehmen, dass sowohl die Veränderungen im Tabak von Erntejahr zu Erntejahr als auch das unterschied- liche Alter der beiden Zigaretten zu Unterschieden in der Rauchchemie führen würden. Mehr als 44 Rauchanalyte einschließlich der meisten als biologisch aktiv angesehenen Verbindungen wurden in dieser Studie quantifiziert. Die Analysen wurden von sechs unabhängigen Labors unter Verwendung unterschiedlicher Analysemethoden durchgeführt. Das Abrauchen der Zigaretten erfolgte gemäß ISO (International Organization for Standardization) Richtlinien. Es waren nur kleine Unterschiede bezüglich Kondensat, Nikotin and Kohlenmonoxid (CO) als auch bei den Aminonaphthalinen, Resorcin und einigen Aldehyden zu beobachten. Obwohl die beiden Referenzzigaretten so identisch wie möglich hergestellt wurden, unterschieden sich die Konzentrationen einer signifikanten Anzahl von Rauchanalyten um $10 \%$ bis $30 \%$. Es gab auch Unterschiede zwischen den beiden Zigaretten hinsichtlich der spezifischen Spurenbestandteile in der Tabakmischung, wie z.B. den Metallen und tabakspezifischen $N$-Nitrosaminen (TSNA), die Einfluss auf die Zusammensetzung des Rauchs haben könnten. Insbesondere der Bleigehalt unterschied sich im Tabak der Zigaretten von 1983 und 2002 sehr stark. [Beitr. Tabakforsch. Int. 20 (2003) 448-458]

\section{RESUME}

Une nouvelle cigarette de référence, $2 \mathrm{R} 4 \mathrm{~F}$, a été conçue pour remplacer la cigarette de référence Kentucky 1R4F. Cette nouvelle cigarette a presque la même composition de mélange que la 1R4F. Toutefois, la cigarette $1 \mathrm{R} 4 \mathrm{~F}$ a été fabriquée en 1983 et il était attendu que les variations du tabac d' une récolte à l' autre ainsi que la différence d' âge entre les deux cigarettes produisent des différences dans la chimie de la fumée. Dans cette étude plus de 44 analytes de la fumée, y compris la plupart des composés considérés comme ayant une activité biologique, ont été dosés. Les analyses ont été réalisées par six laboratoires indépendants faisant appel à plusieurs techniques analytiques. Le fumage a été réalisé selon les conditions normalisées ISO

*Received: $21^{\text {st }}$ January 2003 - accepted: $19^{\text {th }}$ June 2003 
Table 1. Blend data in \% for $1 \mathrm{R} 4 \mathrm{~F}$ and $2 \mathrm{R} 4 \mathrm{~F}$ cigarettes (8)

\begin{tabular}{lrr}
\hline Constituent & 1R4F & 2R4F \\
\hline Flue-cured & 32.54 & 32.51 \\
Burley & 20.04 & 19.94 \\
Maryland & 1.06 & 1.24 \\
Oriental & 11.09 & 11.08 \\
Reconstituted (Schweitzer Process) & 27.17 & 27.13 \\
Glycerin & 2.80 & 2.80 \\
Invert sugar & 5.30 & 5.30 \\
\hline
\end{tabular}

Table 2. Cigarette physical data for $1 \mathrm{R} 4 \mathrm{~F}$ and $2 \mathrm{R} 4 \mathrm{~F}$ cigarettes $(8,9)$

\begin{tabular}{lcc}
\hline Property & 1R4F & 2R4F \\
\hline Filter length (mm) & 27.2 & 27.0 \\
Tipping paper length (mm) & 32.0 & 32.0 \\
Cigarette length (mm) & 84 & 84 \\
Cigarette weight (mg) & 1085 & 1060 \\
Open cigarette pressure drop (cm water) & 13.8 & 12.8 \\
Circumference (mm) & 24.9 & 24.8 \\
Filter ventilation (\%) & 28.4 & 28.0 \\
\hline
\end{tabular}

Table 3. Some blend chemistry data in \% for $2 \mathrm{R} 4 \mathrm{~F}(8)$

\begin{tabular}{l|c|c}
\hline Compound & Mean & Std. dev. \\
\hline Total alkaloids & 2.31 & 0.01 \\
Reducing sugar & 10.70 & 0.14 \\
Glycerin & 2.44 & 0.01 \\
\hline
\end{tabular}

(International Organization for Standardization). Les résultats ne révèlent que de légères différences entre les deux cigarettes en ce qui concerne le goudron, la nicotine, et l' oxyde de carbone, ainsi que les aminonaphthalènes, le résorcinol et certains aldéhydes. Bien que la fabrication des deux cigarettes de référence ait été réalisée de manière aussi proche que possible, les concentrations d' un nombre significatif d'analytes de la fumée présentent des variations entre $10 \%$ et $30 \%$. Les deux cigarettes se distinguent également par rapport à la teneur en éléments traces spécifiques présents dans le mélange, tels que des métaux et des nitrosamines spécifiques du tabac (TSNA), susceptibles d' influencer la composition de la fumée. En particulier, la teneur en plomb est très différente dans le tabac de 1983 et 2002. [Beitr. Tabakforsch. Int. 20 (2003) 448-458]

\section{INTRODUCTION}

The 1R4F cigarette has been used for a long time as a common reference for the analysis of a large number of compounds in mainstream and sidestream smoke. Various publications provide results regarding smoke components for the $1 \mathrm{R} 4 \mathrm{~F}$ cigarette $(1-7)$. However, the $1 \mathrm{R} 4 \mathrm{~F}$ cigarette was made in 1983 and the available stock of cigarettes is significantly reduced. A new cigarette, 2R4F, available from the University of Kentucky, Kentucky Tobacco Research \& Development Center (KTRDC), has been designed as close as possible to the $1 \mathrm{R} 4 \mathrm{~F}$ cigarette with the intention to replace the old reference. Table 1 provides a comparison in the blend composition for the two cigarettes. Table 2 provides a comparison of the cigarette construction. The filler tobacco chemistry of the 1R4F cigarette has been well characterized and presented in various reports $(8,9)$. A few blend chemistry data for the $2 \mathrm{R} 4 \mathrm{~F}$ cigarette are given in Table 3.

An initial collaborative study on basic smoke characteristics (total particulate matter, nicotine, water, Federal Trade Commission (FTC) "tar", puff count, carbon monoxide (CO) and nitric oxide (NO) for the 2R4F was done with seven participating laboratories. This study has been completed and the data has been released by KTRDC (8). An extended evaluation of smoke for $2 \mathrm{R} 4 \mathrm{~F}$ cigarettes including most compounds considered as biologically active (10) is reported in this study. These include "tar", nicotine, and CO (TNC), smoke tobacco specific nitrosamines (TSNA), several aromatic amines, carbonyls, volatiles, phenols, mercury, trace metals, hydrogen cyanide, oxides of nitrogen, polycyclic aromatic hydrocarbons (PAHs) including benzo[a]pyrene, pyridine, quinoline, styrene (PQS), and ammonia. Compounds in the tobacco filler that have a direct impact on these smoke components were also analyzed. These include filler TSNA, mercury, and trace metals.

\section{EXPERIMENTAL}

A number of analytes were measured and six participating laboratories (Lab A to Lab F) used various analytical techniques for sample collection, sample preparation and measurement of the analytes. The smoking was done following International Standard (ISO) recommendations (11-13). Both Borgwaldt RM20 and linear smoking machines were used, depending on the laboratory or the specific analyte.

A list of the analytes and a summary of each analytical technique for the components in smoke for each laboratory are given in Table 4. The analytes measured in the blend and a summary of the analytical techniques applied for this purpose are given in Table 5. As seen from these tables, some techniques were similar or even identical in different laboratories, while other techniques were different.

Each laboratory measured five replicates for each analyte except for "tar", nicotine, and CO where eight replicates were performed for each sample. The data collected from all laboratories were analyzed as indicated below. The set of data for each analyte formed a matrix $\left\{x_{i, j}\right\}$ with the first index " $i$ " indicating the laboratory $(i=1, \ldots p)$ and the second index " $j$ " indicating the replicate $(j=1, \ldots n)$. The total number of laboratories $p$ was generally equal to six, although for some analytes $p<6$. The number of replicates $n=5$, except for "tar", nicotine and CO measurements. Within each laboratory, the average for a lab $\bar{X}_{i}$ and within the laboratory standard deviation (STD) $S_{i}$ were calculated. These were obtained using the typical expressions: 


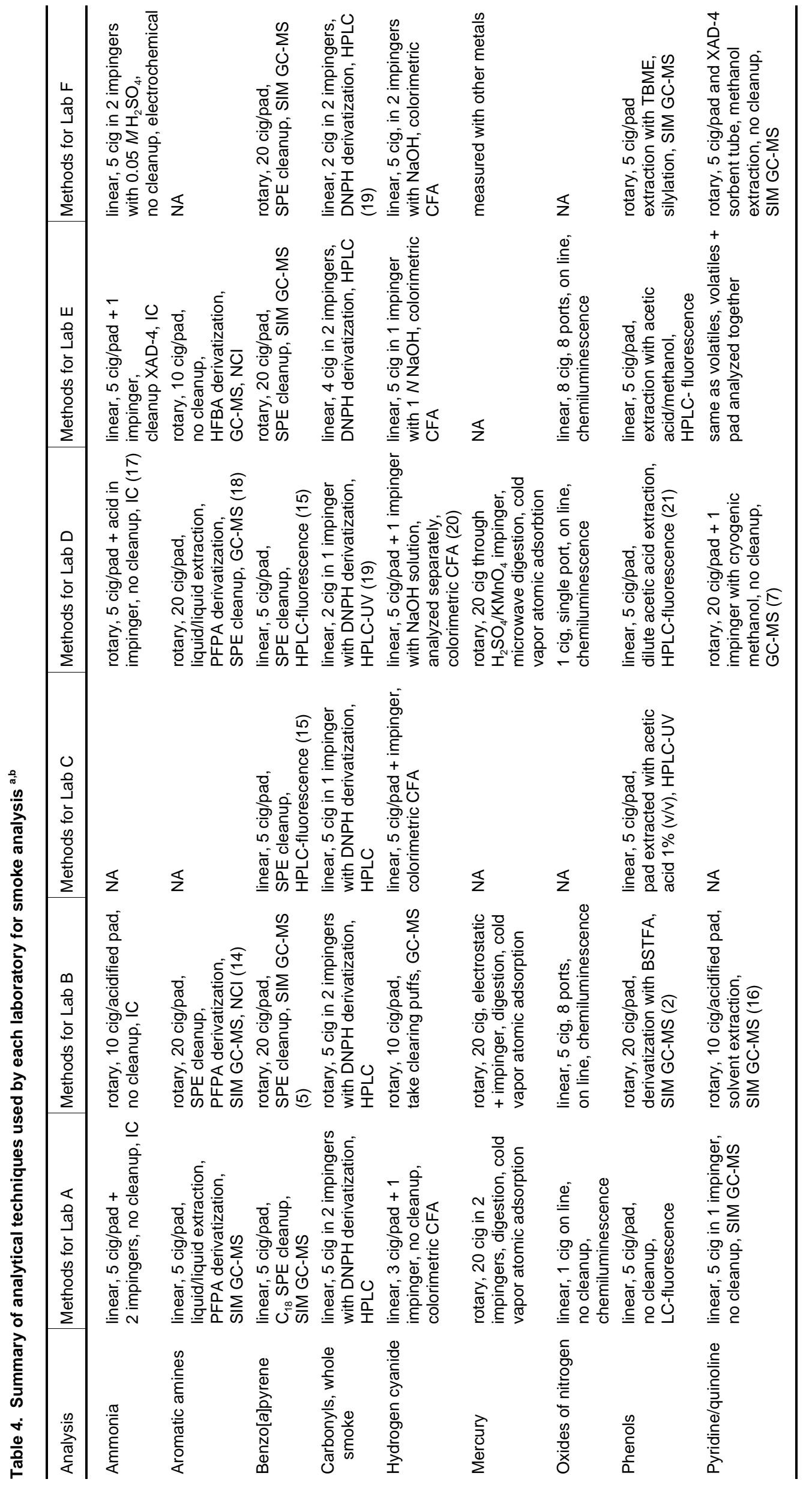




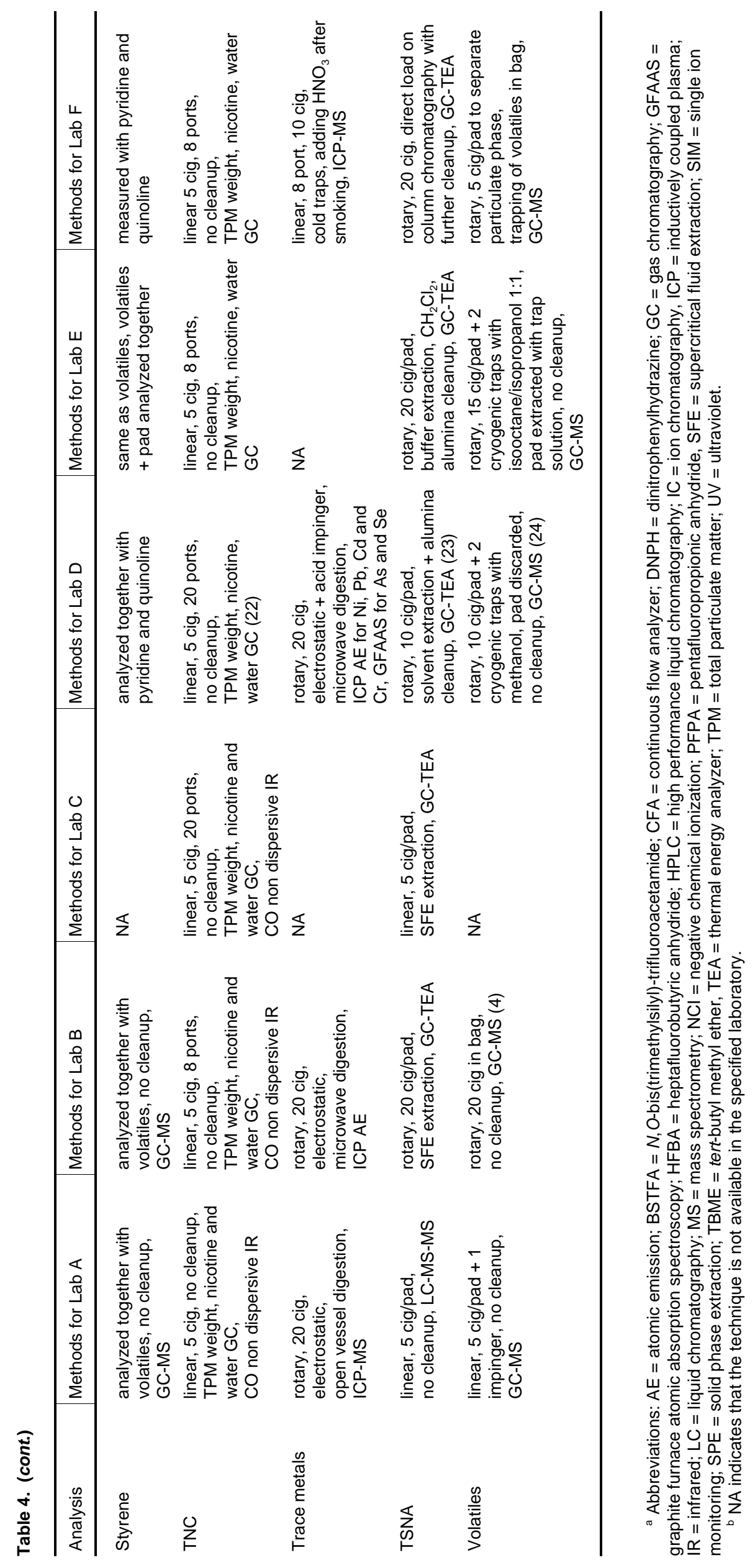


Table 5. Summary of analytical techniques used by each laboratory for filler analysis ${ }^{a, b}$

\begin{tabular}{|c|c|c|c|c|c|c|}
\hline Analysis & Methods for Lab A & Methods for Lab B & Methods for Lab C & Methods for Lab D & Methods for Lab E & Methods for Lab F \\
\hline Blend mercury & NA & $\begin{array}{l}0.3 \mathrm{~g} \text { tobacco, } \\
\text { digestion in open } \\
\text { vessel with } \mathrm{HNO}_{3} \\
+\mathrm{H}_{2} \mathrm{O}_{2} \text {, cold vapor } \\
\text { atomic adsorption }\end{array}$ & NA & $\begin{array}{l}1 \mathrm{~g} \text { freeze dry } \\
\text { tobacco, } \\
\text { microwave } \\
\text { digestion (same } \\
\text { sample as trace } \\
\text { metals), cold } \\
\text { vapor atomic } \\
\text { adsorption }\end{array}$ & $\begin{array}{l}1 \mathrm{~g} \text { tobacco, } \\
\text { digestion in } \mathrm{HNO}_{3} \\
+\mathrm{H}_{2} \mathrm{O}_{2} \text {, then } \\
\text { microwave } \\
\text { digestion }+\mathrm{H}_{2} \mathrm{O}_{2} \\
\text { cold vapor atomic } \\
\text { adsorption }\end{array}$ & $\begin{array}{l}\text { measured with } \\
\text { other metals }\end{array}$ \\
\hline Blend trace metals & NA & $\begin{array}{l}1 \mathrm{~g} \text { tobacco, } \\
\text { digestion in open } \\
\text { vessel with } \mathrm{HNO}_{3} \\
+\mathrm{H}_{2} \mathrm{O}_{2} \text {, ICP-OES }\end{array}$ & NA & $\begin{array}{l}1 \mathrm{~g} \text { freeze dry } \\
\text { tobacco, } \\
\text { microwave } \\
\text { digestion, ICP for } \\
\mathrm{Ni}, \mathrm{Pb}, \mathrm{Cd} \text { and } \mathrm{Cr} \text {, } \\
\mathrm{GFAAS} \text { for As and } \\
\mathrm{Se}\end{array}$ & $\begin{array}{l}1 \mathrm{~g} \text { tobacco, } \\
\text { digestion in } \mathrm{HNO}_{3} \\
+\mathrm{H}_{2} \mathrm{O}_{2} \text {, then } \\
\text { microwave } \\
\text { digestion } \mathrm{H}_{2} \mathrm{O}_{2} \text {, } \\
\mathrm{AA} \text { graphite } \\
\text { furnace, for } \mathrm{As} \\
\text { hydride generation } \\
\text { with } \mathrm{KI}, \mathrm{AA} \\
\text { determination }\end{array}$ & $\begin{array}{l}0.5 \mathrm{~g} \text { tobacco, } \\
\text { microwave } \\
\text { digestion, ICP-MS }\end{array}$ \\
\hline Blend TSNA & $\begin{array}{l}0.25 \mathrm{~g} \text { tobacco, } \\
\text { buffer extraction, } \\
\text { LC-MS-MS }\end{array}$ & $\begin{array}{l}0.5 \mathrm{~g} \text { tobacco, } \\
\text { buffer extraction, } \\
\mathrm{CH}_{2} \mathrm{Cl}_{2}+0.5 \mathrm{~mL} \\
\mathrm{NaOH} 10 \%(\mathrm{w} / \mathrm{w}) \\
\text { GC-TEA }\end{array}$ & $\begin{array}{l}1 \mathrm{~g} \text { tobacco, } \\
\text { extraction with } \\
10 \mathrm{~mL} \mathrm{CH}_{2} \mathrm{Cl}_{2}+ \\
0.5 \mathrm{~mL} \mathrm{NaOH} \\
10 \% \text { (w/w), } \\
\text { GC-TEA }\end{array}$ & $\begin{array}{l}1 \mathrm{~g} \text { tobacco in } \\
\text { ascorbic acid } \\
\text { buffer, Chem Elut } \\
\text { cleanup, GC-TEA }\end{array}$ & $\begin{array}{l}1 \mathrm{~g} \text { tobacco, buffer } \\
\text { extraction, } \\
\text { Chem Elut } \\
\text { cartridge, } \mathrm{CH}_{2} \mathrm{Cl}_{2} \\
\text { elution, GC-TEA }\end{array}$ & $\begin{array}{l}0.5 \mathrm{~g} \text { tobacco, } \\
\text { ASE, cleanup } \\
\text { column } \\
\text { chromotography, } \\
\text { GC-TEA }\end{array}$ \\
\hline
\end{tabular}

${ }^{a}$ Abbreviations: $\mathrm{AA}=$ atomic absorption; $\mathrm{ASE}=$ accelerated solvent extraction; $\mathrm{OES}=$ optical emission spectroscopy.

${ }^{\mathrm{b}} \mathrm{NA}$ indicates that the technique is not available in the specified laboratory.

$$
\begin{aligned}
\bar{X}_{i} & =\frac{1}{n} \sum_{j=1}^{n} x_{i, j} \text { for } i=1,2 \ldots p \text { and } \\
S_{i} & =\sqrt{\frac{1}{n-1} \sum_{j=1}^{n}\left(x_{i, j}-\overline{X_{i}}\right)^{2}}
\end{aligned}
$$

Among labs average $\bar{X}$ and the standard deviation between each laboratory average value $S_{\bar{X}}$ were calculated using the expressions:

$$
\begin{aligned}
\bar{X} & =\frac{1}{p} \sum_{i=1}^{p} \bar{X}_{i}=\frac{1}{p n} \sum_{i=1}^{p} \sum_{j=1}^{n} x_{i, j} \text { and } \\
S_{\bar{X}} & =\sqrt{\frac{1}{p-1} \sum_{i=1}^{p}\left(\bar{X}_{i}-\bar{X}\right)^{2}}
\end{aligned}
$$

The repeatability STD $S_{r}$ and reproducibility STD $S_{-R}$ were further calculated using the expressions:

$$
S_{-r}=\sqrt{\frac{1}{p} \sum_{i=1}^{p} S_{i}^{2}} \text { and } S_{-R}=\sqrt{S_{\bar{X}}^{2}+\frac{n-1}{n} S_{-r}^{2}}
$$

The expression for the coefficients of variation $\mathrm{CV}_{-r}$ for repeatability STD and $\mathrm{CV}_{-R}$ for reproducibility STD were further obtained as:

$$
\mathrm{CV}_{-r}=\frac{S_{-r}}{\bar{X}} 100 \% \text { and } \mathrm{CV}_{-R}=\frac{S_{-R}}{\bar{X}} 100 \%
$$

The two way-ANOVA (analysis of variance) (25) was used for the statistical comparison.

\section{RESULTS AND DISCUSSION}

The results obtained for $1 \mathrm{R} 4 \mathrm{~F}$ and $2 \mathrm{R} 4 \mathrm{~F}$ cigarettes for various groups of analytes in smoke or in filler are given in Tables 6 to 12. Table 6 presents the main results for smoke analysis. The results from Table 6 are summarized in Figure 1. This figure shows the absolute values for the $\%$ differences between $1 \mathrm{R} 4 \mathrm{~F}$ and $2 \mathrm{R} 4 \mathrm{~F}$ smoke data and the corresponding values for $\mathrm{CV}_{-r}$ for the measurements on the two cigarettes. The $\mathrm{CV}_{-r}$ values describe the precision in the analyses that differentiate the two reference cigarettes. As seen from Figure 1, there were small differences between the two cigarettes regarding "tar", nicotine and CO, as well as for aminonaphthalenes, resorcinol, and some aldehydes. The values for $\mathrm{CV}_{-r}$ for about one fourth of the compounds measured in the mainstream smoke of the two cigarettes were larger than $\%$ differences in the average values. For the rest of the analyzed compounds, there were larger differences in the smoke of the two cigarettes than the corresponding $\mathrm{CV}_{-r}$ values. These results showed that although the two reference cigarettes were made as close as possible, smoke deliveries differed for a number of analytes. Differences as large as $10 \%$ to $30 \%$ can be seen between some analyte levels in two cigarettes. The statistical significance of those differences was evaluated using the two way-ANOVA analysis. In Table 6 the differences significant at $95 \%$ confidence level are identified by an asterisk (*), and the differences significant at $99 \%$ confidence level are identified by two asterisks $(* *)$.

Table 7 presents the results for some blend analytes. The results from Table 7 are summarized in Figure 2. This figure shows the absolute values for the $\%$ differences 
Table 6. Results for smoke analysis of $1 \mathrm{R} 4 \mathrm{~F}$ and $2 \mathrm{R} 4 \mathrm{~F}$ cigarettes

\begin{tabular}{|c|c|c|c|c|c|c|c|c|c|c|}
\hline \multirow[b]{2}{*}{ Method } & \multirow[b]{2}{*}{ Analytes } & \multirow[b]{2}{*}{ Unit } & \multirow{2}{*}{$\begin{array}{l}\text { No. of } \\
\text { labs }^{\text {a }}\end{array}$} & \multicolumn{2}{|c|}{ Average } & \multirow[b]{2}{*}{ Rel. diff. $(\%)^{b}$} & \multicolumn{2}{|c|}{$\mathrm{CV}_{-r}{ }^{\mathrm{c}}$} & \multicolumn{2}{|c|}{$\mathrm{CV}_{-R}{ }^{\mathrm{d}}$} \\
\hline & & & & 1R4F & $2 \mathrm{R} 4 \mathrm{~F}$ & & 1R4F (\%) & 2R4F (\%) & 1R4F (\%) & 2R4F (\%) \\
\hline Ammonia & Ammonia & $\mu g / c i g$ & 5 & 12.90 & 11.02 & $-15^{\star \star}$ & 6 & 6 & 18 & 11 \\
\hline \multirow[t]{4}{*}{ Aromatic amines } & 1-Aminonaphthalene & $\mathrm{ng} / \mathrm{cig}$ & 4 & 15.63 & 15.06 & -4 & 8 & 9 & 28 & 23 \\
\hline & 2-Aminonaphthalene & $\mathrm{ng} / \mathrm{cig}$ & 4 & 10.40 & 10.32 & -1 & 10 & 8 & 23 & 22 \\
\hline & 3-Aminobiphenyl & $\mathrm{ng} / \mathrm{cig}$ & $4^{e}$ & 3.20 & 2.97 & $-7^{*}$ & 7 & 10 & 8 & 9 \\
\hline & 4-Aminobiphenyl & $\mathrm{ng} / \mathrm{cig}$ & 4 & 1.94 & 1.73 & $-11^{* *}$ & 7 & 9 & 19 & 21 \\
\hline Benzo[a]pyrene & Benzo[a]pyrene & $\mathrm{ng} / \mathrm{cig}$ & 6 & 5.51 & 6.96 & $26^{* *}$ & 7 & 8 & 23 & 27 \\
\hline \multirow[t]{8}{*}{ Carbonyls } & 2-Butanone & $\mu \mathrm{g} / \mathrm{cig}$ & 6 & 68.08 & 62.72 & $-8^{* *}$ & 7 & 7 & 30 & 25 \\
\hline & Acetaldehyde & $\mu \mathrm{g} / \mathrm{cig}$ & 6 & 623.88 & 560.48 & $-10^{\star *}$ & 6 & 5 & 13 & 15 \\
\hline & Acetone & $\mu \mathrm{g} / \mathrm{cig}$ & $6^{e}$ & 293.15 & 264.74 & $-10^{* *}$ & 6 & 5 & 7 & 5 \\
\hline & Acrolein & $\mu \mathrm{g} / \mathrm{cig}$ & 6 & 60.64 & 58.77 & -3 & 8 & 7 & 16 & 14 \\
\hline & Butyraldehyde & $\mu \mathrm{g} / \mathrm{cig}$ & 6 & 33.93 & 29.58 & $-13^{* *}$ & 9 & 7 & 12 & 9 \\
\hline & Crotonaldehyde & $\mu \mathrm{g} / \mathrm{cig}$ & 6 & 15.90 & 16.18 & 2 & 15 & 11 & 43 & 43 \\
\hline & Formaldehyde & $\mu \mathrm{g} / \mathrm{cig}$ & $6^{e}$ & 22.19 & 21.61 & -3 & 8 & 10 & 9 & 14 \\
\hline & Propionaldehyde & $\mu \mathrm{g} / \mathrm{cig}$ & 6 & 51.54 & 43.92 & $-15^{\star *}$ & 7 & 5 & 15 & 13 \\
\hline Hydrogen cyanide & Hydrogen cyanide & $\mu \mathrm{g} / \mathrm{cig}$ & 5 & 128.93 & 109.20 & $-15^{\star *}$ & 5 & 5 & 10 & 9 \\
\hline \multirow[t]{5}{*}{ Volatiles } & 1,3-Butadiene & $\mu \mathrm{g} / \mathrm{cig}$ & 5 & 32.10 & 29.94 & $-7^{\star *}$ & 7 & 5 & 26 & 25 \\
\hline & Acrylonitrile & $\mu \mathrm{g} / \mathrm{cig}$ & $5^{e}$ & 9.51 & 8.28 & $-13^{* *}$ & 10 & 6 & 16 & 11 \\
\hline & Benzene & $\mu \mathrm{g} / \mathrm{cig}$ & 5 & 44.33 & 43.39 & -2 & 6 & 3 & 19 & 17 \\
\hline & Isoprene & $\mu \mathrm{g} / \mathrm{cig}$ & 5 & 308.08 & 297.68 & $-3^{*}$ & 5 & 4 & 28 & 26 \\
\hline & Toluene & $\mu \mathrm{g} / \mathrm{cig}$ & 5 & 68.08 & 64.91 & $-5^{*}$ & 6 & 4 & 34 & 33 \\
\hline Mercury & Mercury & $\mathrm{ng} / \mathrm{cig}$ & 4 & 5.43 & 3.82 & $-30^{* *}$ & 8 & 9 & 26 & 50 \\
\hline \multirow[t]{2}{*}{ Oxides of nitrogen } & NO & $\mu \mathrm{g} / \mathrm{cig}$ & 2 & 319.88 & 223.41 & $-30^{* *}$ & 8 & 6 & 11 & 13 \\
\hline & $\mathrm{NO}_{x}$ & $\mu \mathrm{g} / \mathrm{cig}$ & 2 & 348.34 & 268.98 & $-23^{* *}$ & 5 & 6 & 6 & 9 \\
\hline \multirow[t]{6}{*}{ Phenols } & Catechol & $\mu \mathrm{g} / \mathrm{cig}$ & $6^{e}$ & 40.57 & 37.90 & $-7^{\star *}$ & 4 & 4 & 7 & 7 \\
\hline & Hydroquinone & $\mu \mathrm{g} / \mathrm{cig}$ & 6 & 42.77 & 32.40 & $-24^{\star *}$ & 5 & 4 & 12 & 14 \\
\hline & $m+p$-Cresol & $\mu \mathrm{g} / \mathrm{cig}$ & $6^{\mathrm{e}}$ & 7.43 & 5.84 & $-21^{* *}$ & 7 & 15 & 21 & 25 \\
\hline & o-Cresol & $\mu \mathrm{g} / \mathrm{cig}$ & $6^{\mathrm{e}}$ & 2.62 & 1.89 & $-28^{\star \star}$ & 6 & 7 & 17 & 14 \\
\hline & Phenol & $\mu \mathrm{g} / \mathrm{cig}$ & 6 & 9.63 & 7.32 & $-24^{\star *}$ & 7 & 7 & 38 & 42 \\
\hline & Resorcinol & $\mu \mathrm{g} / \mathrm{cig}$ & $5^{e}$ & 0.94 & 0.91 & $-3^{*}$ & 3 & 4 & 54 & 54 \\
\hline \multirow[t]{3}{*}{ PQS } & Pyridine & $\mu \mathrm{g} / \mathrm{cig}$ & 5 & 7.47 & 7.02 & -6 & 9 & 10 & 26 & 36 \\
\hline & Quinoline & $\mu \mathrm{g} / \mathrm{cig}$ & 5 & 0.30 & 0.23 & $-22^{* *}$ & 7 & 7 & 23 & 19 \\
\hline & Styrene & $\mu \mathrm{g} / \mathrm{cig}$ & 5 & 6.13 & 5.11 & $-17^{\star *}$ & 10 & 9 & 38 & 45 \\
\hline \multirow[t]{6}{*}{ Trace metals ${ }^{\dagger}$} & Arsenic & $\mathrm{ng} / \mathrm{cig}$ & 3 & 12.21 & 10.39 & -15 & 6 & 18 & 91 & 108 \\
\hline & Cadmium & $\mathrm{ng} / \mathrm{cig}$ & 4 & 55.09 & 47.82 & -13 & 10 & 10 & 30 & 26 \\
\hline & Chromium & $\mathrm{ng} / \mathrm{cig}$ & 2 & 57.74 & 73.01 & 26 & & & & \\
\hline & Lead & $\mathrm{ng} / \mathrm{cig}$ & 4 & 42.51 & 32.95 & -23 & 8 & 22 & 51 & 100 \\
\hline & Nickel & $\mathrm{ng} / \mathrm{cig}$ & 1 & 6.44 & 5.12 & -20 & & & & \\
\hline & Selenium & $\mathrm{ng} / \mathrm{cig}$ & 3 & 39.81 & 34.85 & -12 & 13 & 16 & 118 & 109 \\
\hline \multirow[t]{4}{*}{ TSNA $^{g}$} & NAB & $\mathrm{ng} / \mathrm{cig}$ & 6 & 19.37 & 16.28 & $-16^{\star *}$ & 8 & 8 & 15 & 18 \\
\hline & NAT & $\mathrm{ng} / \mathrm{cig}$ & 6 & 122.49 & 119.02 & -3 & 6 & 7 & 15 & 15 \\
\hline & NNK & $\mathrm{ng} / \mathrm{cig}$ & $6^{e}$ & 90.69 & 115.61 & $27^{\star *}$ & 7 & 6 & 8 & 9 \\
\hline & NNN & $\mathrm{ng} / \mathrm{cig}$ & 6 & 107.09 & 133.11 & $24^{* *}$ & 4 & 6 & 10 & 12 \\
\hline \multirow[t]{4}{*}{ TNC } & TPM & $\mathrm{mg} / \mathrm{cig}$ & 1 & 12.18 & 11.3 & -8 & & & & \\
\hline & Carbon monoxide & $\mathrm{mg} / \mathrm{cig}$ & 6 & 12.26 & 11.96 & -2 & 6 & 4 & 6 & 5 \\
\hline & Nicotine & $\mathrm{mg} / \mathrm{cig}$ & 6 & 0.80 & 0.75 & $-5^{\star *}$ & 5 & 5 & 6 & 6 \\
\hline & "Tar" & $\mathrm{mg} / \mathrm{cig}$ & 6 & 9.38 & 8.91 & $-5^{* *}$ & 4 & 5 & 5 & 6 \\
\hline
\end{tabular}

${ }^{\text {a }}$ No. of labs = number of participating laboratories.

b The relative difference was defined as (2R4F-1R4F)*100\%/1R4F.

${ }^{c} \mathrm{CV}_{r}=$ coefficient of variation of the repeatability standard deviation (26).

${ }^{d} \mathrm{CV}_{R}=$ coefficient of variation of the reproducibility standard deviation (26).

e The results of one laboratory were excluded by Dixon $Q$ outliers test for calculating the summary statistics.

${ }^{f}$ Due to inconsistency of the BQLs (below quantification limits) of laboratories, most results were reported as BQL, no statistical comparison was made.

g TSNA: $N$-nitrosoanabasine (NAB), $N$-nitrosoanatabine (NAT), 4-(N-methylnitrosamino)-1-(3-pyridyl)-1-butanone (NNK), and $N$ nitrosonornicotine (NNN).

* Indicates the differences of the two cigarettes were statistically significant at $95 \%$ confidence level; ${ }^{* *}$ indicates the differences of the two cigarettes were statistically significant at $99 \%$ confidence level. The two way-ANOVA analysis (25) was used for the statistical comparison. 


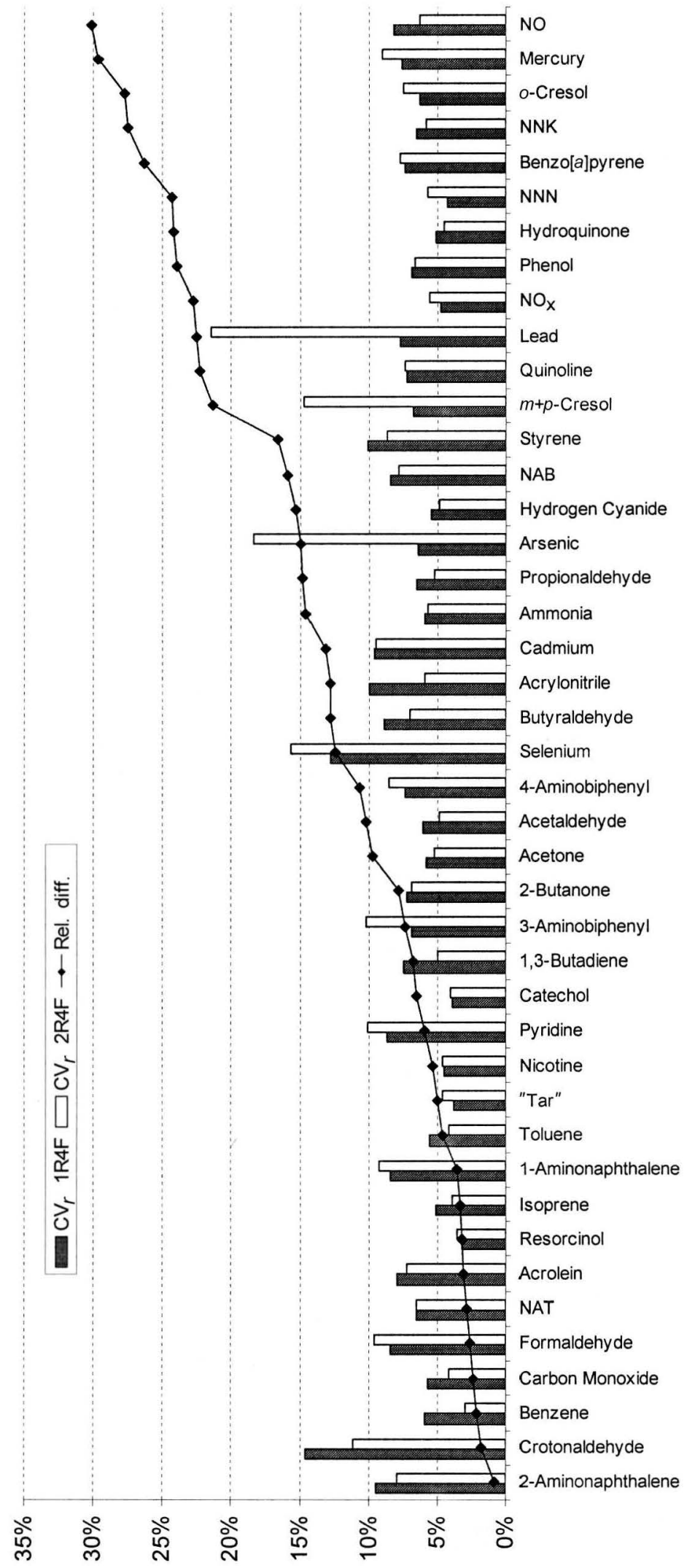

Figure 1. The plot of absolute values for the \% differences between $1 \mathrm{R} 4 \mathrm{~F}$ and $2 \mathrm{R} 4 \mathrm{~F}$ smoke data and the corresponding values for $\mathrm{CV}_{-r}$ for the measurements on the two cigarettes 
Table 7. Results for selected blend compounds in $1 \mathrm{R} 4 \mathrm{~F}$ and $2 \mathrm{R} 4 \mathrm{~F}$ cigarettes

\begin{tabular}{|c|c|c|c|c|c|c|c|c|c|c|}
\hline \multirow[b]{2}{*}{ Method } & \multirow[b]{2}{*}{ Analytes } & \multirow[b]{2}{*}{ Unit } & \multirow[b]{2}{*}{ No. of labs ${ }^{a}$} & \multicolumn{2}{|c|}{ Average } & \multirow[b]{2}{*}{ Rel. diff. (\%) ${ }^{b}$} & \multicolumn{2}{|c|}{$\mathrm{CV}_{-r}{ }^{\mathrm{c}}$} & \multicolumn{2}{|c|}{$\mathrm{CV}_{-R}{ }^{\mathrm{d}}$} \\
\hline & & & & 1R4F & 2R4F & & 1R4F (\%) & 2R4F (\%) & 1R4F (\%) & 2R4F (\%) \\
\hline Blend mercury & Blend mercury & $\mu g / g$ & 4 & 0.05 & 0.06 & 23 & 13 & 21 & 55 & 98 \\
\hline \multirow{7}{*}{$\begin{array}{l}\text { Blend trace } \\
\text { metals }\end{array}$} & & & & & & & & & & \\
\hline & Blend arsenic & $\mu g / g$ & 4 & 0.85 & 0.77 & -10 & 16 & 11 & 69 & 55 \\
\hline & Blend cadmium & $\mu \mathrm{g} / \mathrm{g}$ & 4 & 1.46 & 1.44 & -1 & 5 & 3 & 19 & 22 \\
\hline & Blend chromium & $\mu \mathrm{g} / \mathrm{g}$ & 4 & 1.64 & 2.18 & $33^{* *}$ & 7 & 13 & 49 & 77 \\
\hline & Blend lead & $\mu \mathrm{g} / \mathrm{g}$ & 4 & 1.91 & 0.72 & $-62^{* *}$ & 8 & 8 & 27 & 34 \\
\hline & Blend nickel & $\mu g / g$ & 4 & 2.18 & 2.53 & $16^{\star *}$ & 9 & 10 & 22 & 39 \\
\hline & Blend selenium & $\mu g / g$ & $4^{e}$ & 2.98 & 1.49 & $-50^{\star \star}$ & 12 & 27 & 134 & 168 \\
\hline \multirow[t]{4}{*}{ Blend TSNA } & Blend NAB & $\mathrm{ng} / \mathrm{g}$ & 5 & 118.14 & 140.55 & $19^{* *}$ & 12 & 7 & 25 & 16 \\
\hline & Blend NAT & $\mathrm{ng} / \mathrm{g}$ & $5^{\mathrm{e}}$ & 1991.75 & 2473.78 & $24^{* *}$ & 4 & 2 & 4 & 3 \\
\hline & Blend NNK & $\mathrm{ng} / \mathrm{g}$ & 5 & 1173.02 & 1791.49 & $53^{* *}$ & 4 & 4 & 11 & 13 \\
\hline & Blend NNN & $\mathrm{ng} / \mathrm{g}$ & 5 & 2354.44 & 3539.21 & $50^{\star *}$ & 3 & 3 & 6 & 3 \\
\hline
\end{tabular}

${ }^{a}$ No. of labs $=$ number of participating laboratories.

${ }^{\mathrm{b}}$ The relative difference was defined as $(2 \mathrm{R} 4 \mathrm{~F}-1 \mathrm{R} 4 \mathrm{~F}){ }^{\star} 100 \% / 1 \mathrm{R} 4 \mathrm{~F}$.

${ }^{\circ} \mathrm{CV}_{r}=$ coefficient of variation of the repeatability standard deviation (26).

${ }^{\mathrm{d}} \mathrm{CV}_{R}=$ coefficient of variation of the reproducibility standard deviation (26).

${ }^{\mathrm{e}}$ The results of one laboratory were excluded by Dixon $\mathrm{Q}$ outliers test for calculating the summary statistics.

* Indicates the differences of the two cigarettes were statistically significant at $95 \%$ confidence level; ${ }^{* *}$ indicates the differences of the two cigarettes were statistically significant at $99 \%$ confidence level. The two way-ANOVA analysis (25) was used for the statistical comparison.

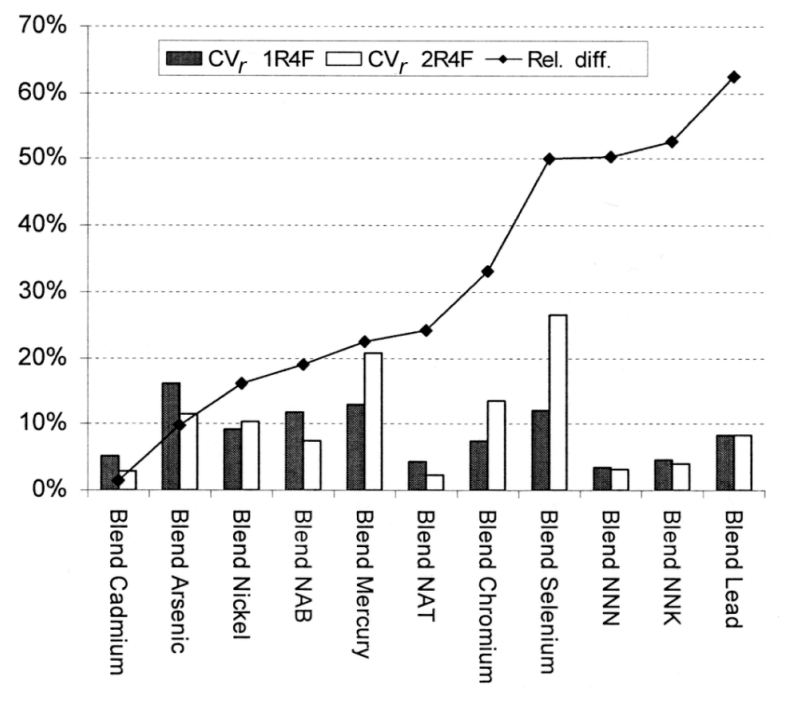

Figure 2. The plot of absolute values for the \% differences between $1 \mathrm{R} 4 \mathrm{~F}$ and $2 \mathrm{R} 4 \mathrm{~F}$ selected blend compounds, and the corresponding values for $\mathrm{CV}_{-r}$ for the measurements on the two cigarettes

between 1R4F and 2R4F selected blend compounds data, and the corresponding values for $\mathrm{CV}_{-r}$ for the measurements on the two cigarettes. As seen from Figure 2, specific trace compounds such as metals and TSNA were different in the blend of the two cigarettes. The level of lead, in particular, was very different in tobacco between 1983 and 2002.

Table 6 and Table 7 also contain $\mathrm{CV}_{-R}$ data for the analytical measurements used in this study. The $\mathrm{CV}_{-R}$ values can be used to characterize the discrepancy between the labs in the measurement of a specific analyte and should not be used in the comparison between the two cigarettes.
Table 8. Results for carbonyl compounds in $\mu \mathrm{g} / \mathrm{cig}$ obtained using a GC-MS technique

\begin{tabular}{l|r|r|r|r}
\hline \multirow{2}{*}{ Analytes } & \multicolumn{2}{|c|}{ Average $(\mu \mathrm{g} / \mathrm{cig})$} & \multicolumn{2}{c}{ Std. dev. $(\mu \mathrm{g} / \mathrm{cig})$} \\
\cline { 2 - 5 } & \multicolumn{1}{|c}{ 1R4F } & \multicolumn{1}{c}{ 2R4F } & \multicolumn{1}{c}{ 1R4F } & \multicolumn{1}{c}{ 2R4F } \\
\hline Acetaldehyde & 619.36 & 583.74 & 33.99 & 13.18 \\
Acetone & 233.88 & 261.62 & 42.45 & 7.35 \\
Acrolein & 47.08 & 50.34 & 3.15 & 1.61 \\
2-Butanone & 69.86 & 73.48 & 6.23 & 1.44 \\
Butyraldehyde & 12.64 & 12.64 & 0.26 & 0.21 \\
Crotonaldehyde & 18.50 & 20.06 & 0.91 & 0.87 \\
Formaldehyde & 22.90 & 23.16 & 3.39 & 2.14 \\
Propionaldehyde & 46.50 & 43.96 & 2.63 & 0.97 \\
\hline
\end{tabular}

Nevertheless, each $\mathrm{CV}_{-R}$ value is a parameter that can be used in judging the accuracy of the result for a specific analyte.

One laboratory analyzed certain carbonyl compounds in mainstream smoke using both high performance liquid chromatography (HPLC) and gas chromatography-mass spectrometry (GC-MS) techniques. The results from the HPLC method are included in Table 6 together with the data from the other five laboratories. The GC-MS technique was based on the dinitrophenylhydrazine (DNPH) derivatization of carbonyl compounds followed by analysis. The data generated by the GC-MS method are shown in Table 8 . The data from Table 8 are slightly lower than the averages shown in Table 6, but in general are in good agreement with those data. However, the results for butyraldehyde were significantly lower by the GC-MS method. The GC-MS method detected 2-methylpropanal at levels about twice those for $n$-butyraldehyde. It is likely that the butyraldehyde reported by the methods using HPLC for separation and detection was not differentiated from the $\mathrm{C}_{4}$ aldehyde isomer. 
Table 9. Results for carbonyl compounds ( $\mu \mathrm{g} / \mathrm{cig}$ ) in the vapor phase of $1 \mathrm{R} 4 \mathrm{~F}$ and $2 \mathrm{R} 4 \mathrm{~F}$ cigarettes

\begin{tabular}{l|rr|r|r}
\hline \multirow{2}{*}{ Analytes } & \multicolumn{2}{|c|}{ Average $(\mu \mathrm{g} / \mathrm{cig})$} & \multicolumn{2}{c}{ Std. dev. $(\mu \mathrm{g} / \mathrm{cig})$} \\
\cline { 2 - 5 } & \multicolumn{1}{|c|}{ 1R4F } & 2R4F & \multicolumn{1}{c}{ 1R4F } & 2R4F \\
\hline Acetaldehyde & 484.46 & 396.78 & 43.10 & 71.02 \\
Acetone & 209.58 & 205.52 & 12.26 & 8.35 \\
Acrolein & 45.96 & 44.84 & 3.13 & 2.52 \\
2-Butanone + & & & & \\
$\quad n$-butyraldehyde & 39.52 & 40.94 & 4.65 & 3.62 \\
Crotonaldehyde & 6.64 & 7.1 & 0.46 & 0.70 \\
2-Methylpropanal & 8.08 & 8.1 & 0.34 & 0.39 \\
Propionaldehyde & 32.14 & 29.6 & 3.27 & 2.75 \\
\hline
\end{tabular}

Table 10. Results for other aromatic amines (ng/cig) in the mainstream smoke of $1 \mathrm{R} 4 \mathrm{~F}$ and $2 \mathrm{R} 4 \mathrm{~F}$ cigarettes

\begin{tabular}{lrrr|r}
\hline \multirow{2}{*}{ Analytes } & \multicolumn{2}{c|}{ Average (ng/cig) } & \multicolumn{2}{c}{ Std. dev. (ng/cig) } \\
\cline { 2 - 5 } Aniline & 1R4F & 2R4F & \multicolumn{1}{c}{ 1R4F } & 2R4F \\
Benzidine & 331.40 & 251.60 & 16.88 & 18.09 \\
2,4-Dimethylaniline & 0.11 & 0.09 & 0.02 & 0.02 \\
2,5-Dimethylaniline & 19.06 & 15.12 & 1.51 & 2.16 \\
2,6-Dimethylaniline & 6.28 & 12.46 & 1.17 & 1.91 \\
2-Ethylaniline & 8.75 & 6.93 & 0.63 & 0.53 \\
3,4-Dimethylaniline & 13.32 & 8.23 & 0.67 & 0.89 \\
3,5-Dimethylaniline & 9.05 & 6.77 & 0.64 & 1.17 \\
3-Ethylaniline & 10.09 & 7.96 & 0.74 & 1.07 \\
4-Ethylaniline & 8.75 & 6.48 & 0.59 & 1.02 \\
m-Toluidine & 55.22 & 46.26 & 0.57 & 4.71 \\
o-Toluidine & 49.76 & 42.42 & 0.59 & 2.72 \\
p-Toluidine & 41.56 & 29.68 & 1.57 & 3.23 \\
Tolidine & 0.03 & $\mathrm{ND}^{\mathrm{a}}$ & 0.02 & - \\
\hline
\end{tabular}

${ }^{\text {a }} \mathrm{ND}=$ not detected

The carbonyl compounds in the vapor phase of the two reference cigarettes were also measured in only one laboratory. Twenty cigarettes were smoked on a rotary machine and the vapor phase collected in a plastic smoke bag (4). The vapor phase was then immediately injected in a GC-MS system equipped with a PoraPlot $Q$ type column (from Chrompack/Varian). The data are shown in Table 9. As expected, the levels of the carbonyl compounds in vapor phase were lower than those in total mainstream smoke. The compound 2-methylpropanal was also identified in the vapor phase of mainstream smoke.

In addition to the commonly analyzed aminonaphthalenes and aminobiphenyls, a number of other aromatic amines present in smoke were measured by one of the participating laboratories. The results for these amines are given in Table 10. A number of other PAHs present in smoke, besides benzo $[a]$ pyrene, were also measured by one of the participating laboratories. The results for these PAHs are given in Table 11. The results from Tables 10 and 11 show differences between the two reference cigarettes in the same range as for other analytes (up to about $30 \%$ ). The aromatic amines are typically lower in the $2 \mathrm{R} 4 \mathrm{~F}$ cigarette while the PAHs are lower in $1 \mathrm{R} 4 \mathrm{~F}$ (except for naphthalene).
Table 11. Results for other polycyclic aromatic hydrocarbons $(\mathrm{ng} / \mathrm{cig})$ in the mainstream smoke of $1 \mathrm{R} 4 \mathrm{~F}$ and $2 \mathrm{R} 4 \mathrm{~F}$ cigarettes

\begin{tabular}{lrr|r|r}
\hline \multirow{2}{*}{ Analytes } & \multicolumn{2}{c|}{ Average (ng/cig) } & \multicolumn{2}{c}{ Std. dev. (ng/cig) } \\
\cline { 2 - 5 } Anthracene & 1R4F & 2R4F & 1R4F & 2R4F \\
Benzanthracene & 39.16 & 45.82 & 2.14 & 4.17 \\
Benzo[e]pyrene & 10.37 & 14.48 & 0.89 & 0.89 \\
Benzofluoranthene & 3.60 & 4.67 & 0.17 & 0.39 \\
Benzofluorene & 29.38 & 10.24 & 0.64 & 0.70 \\
Benzoperylene & 1.16 & 34.20 & 2.05 & 2.90 \\
Chrysene & 15.66 & 20.50 & 0.06 & 0.15 \\
Dibenanthrancene & 0.38 & 0.46 & 0.57 & 2.12 \\
Fluoranthene & 46.04 & 56.20 & 1.54 & 0.09 \\
Fluorene & 116.40 & 119.80 & 9.07 & 6.28 \\
Naphthalene & 339.60 & 271.60 & 20.77 & 18.74 \\
Perylene & 0.67 & 0.88 & 0.09 & 0.11 \\
Phenanthrene & 94.14 & 125.20 & 4.86 & 11.01 \\
Pyrene & 29.64 & 39.20 & 1.56 & 239 \\
\hline
\end{tabular}

Table 12. Results for nicotine, ammonia and some minor alkaloids ( $\mathrm{mg} / \mathrm{g}$ tobacco) for $1 \mathrm{R} 4 \mathrm{~F}$ and $2 \mathrm{R} 4 \mathrm{~F}$ cigarettes

\begin{tabular}{l|rr|r|r}
\hline \multirow{2}{*}{ Analytes } & \multicolumn{2}{|c|}{ Average (ng/cig) } & \multicolumn{2}{c}{$\mathrm{CV}_{-r}$} \\
\cline { 2 - 5 } Nicotine & \multicolumn{1}{|c}{ 1R4F } & 2R4F & 1R4F & 2R4F \\
Ammonia & 17.83 & 19.66 & 1.30 & 1.16 \\
Anabasine & 805.14 & 1429.46 & 1.71 & 3.56 \\
Anatabine & 0.14 & 0.14 & 3.30 & 2.82 \\
Myosmine & 0.83 & 0.90 & 0.91 & 1.38 \\
Nornicotine & 0.08 & 0.10 & 5.65 & 5.65 \\
& 0.83 & 1.16 & 3.61 & 3.27 \\
\hline
\end{tabular}

Two laboratories also determined the level of nicotine, ammonia, and of several minor alkaloids in the tobacco blend. The results are shown in Table 12. Although the nicotine levels in the 1R4F blend were lower than in 2R4F the level of this compound in smoke was slightly higher in $1 \mathrm{R} 4 \mathrm{~F}$ cigarettes. The same observation can be made for ammonia and smoke ammonia in the two cigarettes.

\section{CONCLUSIONS}

A number of analytes in smoke including most compounds considered as biologically active were analyzed in $1 \mathrm{R} 4 \mathrm{~F}$ and 2R4F Kentucky reference cigarettes. A few compounds in the tobacco section that may be transferred in smoke were also analyzed. The study was done in six independent laboratories to generate generally accepted average values for the specific analytes measured in this study. The cigarettes were smoked following ISO recommendations. The results showed that regarding "tar", nicotine and $\mathrm{CO}$, there are only small differences between the two cigarettes. The same situation was true for a few compounds such as aminonaphthalenes, resorcinol, and some aldehydes. For the rest of the analyzed compounds there were larger differences in the smoke of the two cigarettes. Although the two reference cigarettes were made as close as possible, a significant number of analytes differed $10 \%$ to $30 \%$ between the two cigarettes. 


\section{ACKNOWLEDGEMENT}

The analytical data for this study were provided by Arista Laboratories (Dr. R. Higby, Dr. K. Wagner and their team), Labstat International Inc. (Dr. W. Rickert, Mr. P. Joza and their team), Brown and Williamson Tobacco Corp. (Mr. R. Honeycutt, Mr. M. Abhulimen, Dr. C. Taylor, Dr. S. Moldoveanu and their team), Imperial Tobacco Canada Limited (Dr. J. Dumont and his team), Souza Cruz S.A. (Dr. J.R. Silva and his team), BAT Southampton (Dr. K. McAdam, Ms. H. Taylor, Dr. P. Bevan and their team).

\section{REFERENCES}

1. Borgerding, M.F., J.A. Bodnar, H.L. Chung, P.P. Mangan, C.C. Mossison, C.H. Risner, J.C. Rogers, D.F. Simmons, M. S. Uhrig, F.N. Wendelboe, D.E. Wingate, and L.S. Winkler: Chemical and biological studies of a new cigarette that primarily heats tobacco. Part 1 . Chemical composition of mainstream smoke; Food Chem. Toxicol. 36 (1997) 169-182.

2. Forehand, J.B., G.L. Dooly, and S.C. Moldoveanu: Analysis of polycyclic aromatic hydrocarbons, phenols and aromatic amines in particulate phase cigarette smoke using simultaneous distillation and extraction as a sole sample clean-up step; J. Chromatogr. A, 898 (2000) 111-124.

3. Risner, C.H.: The determination of benzo $[a]$ pyrene in the total particulate matter of cigarette smoke; J. Chromatogr. Sci. 26 (1988) 113-120.

4. Dong, J.Z., J.N. Glass, and S.C. Moldoveanu: A simple GC-MS technique for the analysis of vapor phase mainstream cigarette smoke; J. Microcolumn Sep. 12 (2000) 142-152.

5. Zha, Q., N.X. Qian, and S.C. Moldoveanu: Analysis of polycyclic aromatic hydrocarbons in particulate phase of cigarette smoke using a gas chromatographic-high resolution mass spectrometric technique; J. Chromatogr. Sci. 40 (2002) 403-408.

6. Chepiga, T.A., M.J. Morton, P.A. Murphy, J.T. Avalos, B.R. Bombick, D.J. Doolittle, M.F. Borge ding, and J.E. Swauger: A comparison of mainstream and sidestream smoke chemistry and mutagenicity of a representative sample of the US cigarette market with two Kentucky reference cigarettes (K1R4F and K1R5F); Food Chem. Toxicol. 38 (2000) 949-962.

7. White, E.L., M.S. Uhrig, T.J. Johnson, B.M. Gordon, R.D. Hicks, M.F. Borgerding, W.M. Coleman III, and J.F. Elder Jr.: Quantitative determination of selected compounds in a Kentucky 1R4F reference cigarette smoke by multidimensional gas chromatography and selected ion monitoring-mass spectrometry; J. Chromatogr. Sci. 28 (1990) 393-399.

8. Davies, H.M. and A. Vaught: The reference cigarette: Kentucky Tobacco Research \& Development Center (KTRDC), Lexington, KY, 2003.

9. Baker, T.V., J.M. Biltz, F. Carriedo, N.P. Kulshreshtha, J.H. Lauterbach, S.C. Moldoveanu, and W.T. Pannell: Tobacco chemical and cigarette physical analyses on Kentucky reference cigarettes; 52nd Tobacco Science Research Conference, Sept. 1998, Atlanta, GA.
10. Hoffmann, D. and I. Hoffmann: Tobacco smoke components; Beitr. Tabakforsch. Int. 18 (1998) 49-52.

11. ISO 3308: Routine analytical cigarette smoking machine - Definitions and standard conditions; Reference number ISO 3308:1991 (E), International Organization for Standardization, Geneva, Switzerland, 1991.

12. ISO 3402: Tobacco and Tobacco Products - Atmosphere for conditioning and testing; Reference number ISO 3402:1991(E), International Organization for Standardization, Geneva, Switzerland, 1991.

13. ISO 4387: Cigarettes - Determination of total and nicotine free dry particulate matter using a routine analytical smoking machine; Reference number ISO 4387:1991 (E), International Organization for Standardization, Geneva, Switzerland, 1991.

14. Smith, C.J.; G.L. Dooly, and S.C. Moldoveanu: A new technique using solid phase extraction (SPE) for the analysis of aromatic amines in mainstream cigarette smoke; J. Chromatogr. A. 991 (2003) 99-107.

15. Dumont, J., F. Laroque-Lazure, and C. Iorio: An alternative isolation process for the subsequent determination of benzo $[a]$ pyrene in total particulate matter of cigarette smoke; J. Chromatogr. Sci. 31 (1993) 371-374.

16. Kulshreshtha, N.P. and S.C. Moldoveanu: Analysis of pyridines in mainstream cigarette smoke; J. Chromatogr. A 985 (2003) 303-312.

17. Nanni, E.J., M.E. Lovette, R.D. Hicks, K.W. Fowler, and M.F. Borgerding: Separation and quantitation of monovalent and cationic species in mainstream cigarette smoke, aerosols by high performance ion chromatography; J. Chromatogr. Sci. 28 (1990) 432-436.

18. Pieraccini, G., F. Luceri, and G.Moneti: New gas chromatographic/mass spectrometric method for the quantitative analysis of primary amines in main and side-stream cigarette smoke; Rapid Commun. Mass Spectrom. 6 (1992) 406-409.

19. Houlgate, P.R., K.S. Dhingra, J.S. Nash, and W.H. Evans: Determination of formaldehyde and acetaldehyde in mainstream cigarette smoke by high-performance liquid chromatography; Analyst 114 (1989) 355-360.

20. Rickert, W.S. and P.B. Stockwell: Automatic determination of hydrogen cyanide, acrolein and total aldehydes in the gas phase of tobacco smoke; J. Autom. Chem. 1 (1979) 152-154.

21. Risner, C.H. and S.L. Cash: A high performance liquid chromatographic determination of major phenolic compounds in tobacco smoke; J. Chromatogr. Sci. 28 (1990) 239-243.

22. Wagner, J.R.: Gas chromatographic determination of nicotine contained on Cambridge pads; Annual Meeting of the Association of Official Analytical Chemists, Oct. 1978 (45) Fed. Reg. 46483, 1980.

23. Fischer, S. and B. Spiegelhalder: Improved method for the determination of tobacco specific nitrosamines (TSNA) in tobacco smoke; Beitr. Tabakforsch. Int. 14 (1989) 145-153.

24. Brunnemann, K.D., M.R. Kagan, J. Cox., and D. Hoffmann: Analysis of 1,3-butadiene and other selected gas-phase components in cigarette mainstream and side- 
stream smoke by gas chromatography-mass selective detection; Carcinogenesis 11 (1990) 1863-1868.

25. Scheffé, H.: The nalysis of variance; J. Wiley, New York, N.Y., 1959.

26. 1998 Annual book of ASTM standards; Designation: E691 - 92, ASTM, West Conshohocken, 1998.
Address for correspondence

Serban Moldoveanu

Brown and Williamson Tobacco Corporation,

Macon, GA, 31217, USA

Email: smoldov@aol.com 